ISSN1027-5495. Functional Materials, 23, No.3 (2016), p. 502-508

\title{
Study on effect of the inner vortex finder length on the flow properties of the hydrocyclone with double vortex finders
}

\author{
Yuekan Zhang, Peikun Liu, Xinghua Yang, \\ Junru Yang, Linjing Xiao
}

\author{
College of Mechanical \& Electronic Engineering Shandong University of \\ Science and Technology, Qingdao, Shandong 266590, R.P. China
}

Received April 30, 2016

\begin{abstract}
The traditional hydrocyclone can only obtain two products: overflow and underflow. In the paper, we propose three-products hydrocyclone with double vortex finders. The hydrocyclone is designed with two coaxial overflow tubes with different diameters. During overflow, light and fine particles exit from the inner overflow tube. The mid-size particles overflow from the outer overflow tube, and the coarse particles through the underflow pipe. Therefore, one classification can obtain three different narrow-grade-classification products. The inner vortex finder length is the important influent factor on the flow performance of the hydrocyclone. This paper is mainly focused on the study of the flow field of both the air and the liquid phase, and of the effects of the inner vortex finder length on the velocity field, pressure field and the air column of the hydrocyclone with double vortex finders.

Keywords: inner vortex finder length, hydrocyclone with double vortex finders, numerical simulation; flow properties
\end{abstract}

Разработан и исследован гидроциклон с двумя коаксиальными переливными трубками различного диаметра. Во время переполнения, малые легкие, частицы выходят из внутренней трубы слива. Среднего размера частицы выходят из внешней трубы, а крупные частицы через нижнюю трубу. Поэтому при одном цикле можно разделить три размера частиц. Показано, что внутренняя длина завихрения является важным фрактором, влияющим на производительность гидроциклона. Эта статья сосредоточена на изучении процесса течения как газовой, так и жидкой фазы. Исследуются влияние внутренней длины завихрения на скорость и давление воздушного столба гидроциклона с двойными вихревыми искателями.

Дослідження впливу внутрішньої довжини турбулентності на властивості реологій гідроциклона з подвійними вихровими шукачами. Яхан Чжан, Пейкун Ліу, Синхуа Ян, Джунру Ян, Лінян Сяо

Розроблений і досліджений гідроциклон з двома коаксіальними переливними трубками різного діаметру. Під час переповнювання, малі, легені, частинки виходять з внутрішньої труби зливу. Середнього розміру частинки виходять із зовнішньої труби, а крупні частинки через нижню трубу. Тому при одному циклі можна розділити три розміри частинок. Показано, що внутрішня довжина завихорення є важливим чинником, що впливає на продуктивність гідроциклона. Ця стаття зосереджена на вивченні процесу перебігу як газової, так і рідкої фази. Досліджуються вплив внутрішньої довжини завихорення на швидкість і тиск повітряного стовпа гідроциклона з подвійними вихровими шукачами. 


\section{Introduction}

Based on the principle of centrifugal sedimentation, the cyclone is a very efficient equipment in classifying particles into different sizes[1-2]. For traditional cyclone separators, only two products, the overflow and the underflow, can be obtained with each having too wide a size distribution. Here, we propose a new design that comes with two overflow pipes, as shown in Figure 1. In comparison to traditional separators, the new design adds an extra coaxial overflow pipe with a smaller diameter to the original one. Generally, the pipe with the larger diameter is called the external overflow pipe, while the one with the smaller diameter the internal overflow pipe. By designing the cyclone separator with two overflow pipes, the fine and light particles in the fluid will flow through the internal overflow pipe; middle-sized particles through the external overflow pipe; and the coarse particles through the underflow pipe. So one classification can obtain three different narrow-grade-classification products: inner overflow, outer overflow, and underflow.

\section{Experimental}

\subsection{Model building of the flow field}

This paper is mainly focused on the study of the flow field of both the air and the liquid phase, and of the effects of the immersion depth of the internal overflow pipe on the velocity field, pressure field and the air column. The schematic of the new design is shown in Figure 2 with structural parameters described in Table 1. The structure is meshed using ICEM software (Figure 3) and there are 140577 nodes in total.

\subsection{Initial and boundary conditions}

(1) Flow-in conditions: the flow-in velocity is $5 \mathrm{~m} / \mathrm{s}$. the main phase is water and the second-
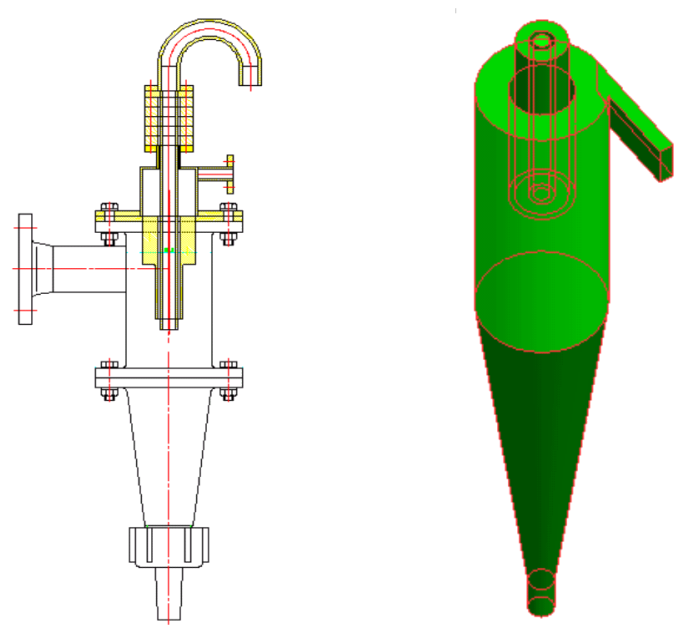

Fig. 1 Structure diagram of the hydrocyclone with double vortex finders

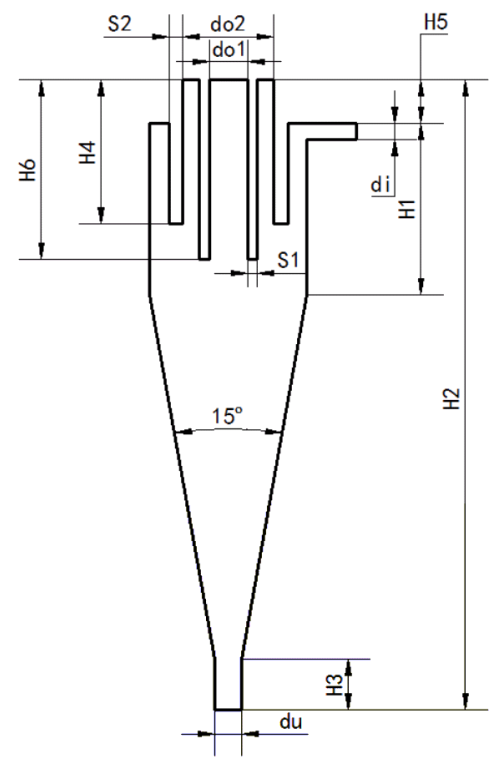

Fig. 2 Flow field of cyclone with double vortex finder

Table 1 Main structural parameters of the hydrocyclone with double vortex finders

\begin{tabular}{|c|c|}
\hline Structural parameter & Structural dimensions \\
\hline Hydrocyclone diameter D, mm & 50 \\
\hline Inner vortex finder diameter do1, mm & 6 \\
\hline Outer vortex finder diameter do2, mm & 20 \\
\hline Underflow port diameter du, mm & 6 \\
\hline Feed inlet equivalent diameter di, mm & 12 \\
\hline Outer overflow pipe insertion depth $\mathrm{H} 4, \mathrm{~mm}$ & 85 \\
\hline Inner overflow pipe insertion depth $\mathrm{H} 6, \mathrm{~mm}$ & $65,75,85,95,105$ \\
\hline Thickness of the overflow pipe s1, s2, mm & $2,2.5$ \\
\hline Extension length of the overflow pipe H5, mm & 28 \\
\hline Cylinder height H1, mm & 116 \\
\hline total height H2, mm & 310 \\
\hline Underflow pipe height H3, mm & 15 \\
\hline
\end{tabular}




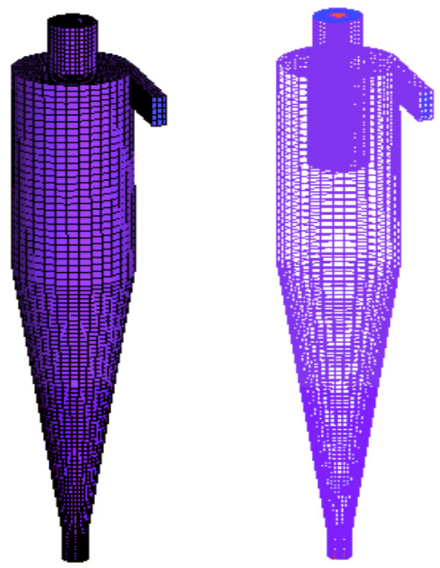

Fig. 3 Meshes of the hydrocyclone

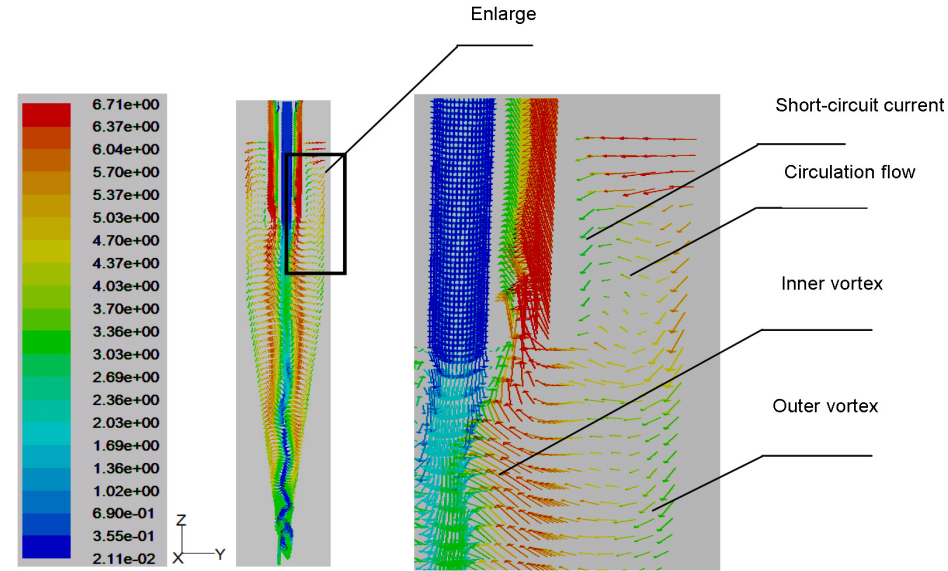

Fig. 4 Flow field vectors in hydrocyclone with double vortex finders ary phase is air. The turbulence is characterized by its intensity and the hydraulic diameter.

(2) Flow-out conditions: both the overflow and the underflow outlets are pressure controlled and in contact with the air. The reflux ratio for the air is 1 .

(3) Wall conditions: frictionless and the standard wall function was used to calculate the turbulence properties[3].

(4) VOF model is adopted for multiphase flow; RSM model for turbulence model[4-10]; SIMPLE method for pressure-velocity coupling; PRESTO method for pressure discretion scheme; QUICK method for momentum discretion scheme. Geo-Reconstruct method for the volume percentage of two phases.

\section{Results and discussion}

\subsection{Flow field for the cyclone with double vortex finders}

Set the residual error as $10^{-4}$ and time step as $10^{-4} \mathrm{~S}$ and computed with the unsteady method after initialization. The vector diagram of the flow field was obtained and shown in Figure 4.

As can be seen from Figure 4, when the fluid comes into the cyclone separator in the tangent direction, its flow has a pattern. The fluid is swirling downwards against the wall and as it is moving, some of the fluid leaves the wall and moves towards the axis and upwards simultaneously to the two overflow pipes. Part of that fluid enters the external pipe and the rest the internal overflow pipe. So according to the flow partition, three products with different size distributions can be obtained at the external overflow pipe, the internal overflow pipe and the underflow pipe. It is also worth noting from Figure 4 that there is a little amount of fluid at the external wall of the overflow pipes just directly entering into them at the immersion depth with being separated, which what we called short-circuit flow. In addition, there is very limited amount of liquid cycling between the external walls of the overflow pipes and the inside wall of the cyclone separator.

\subsection{Effect of the inner vortex finder length on the flow properties of the cyclone}

The immersion depth of the overflow pipes is a very important parameter as different depths represent different pathways and stay times for the fluid moving upwards along the axis, and hence result to products with different particle sizes. So it is essential to study the effect of the immersion depth on the flow field and therefore to determine a reasonable depth. In this work, we select 5 different immersion depths: $65,75,85,95$ and $105 \mathrm{~mm}$. Unless otherwise specified, the immersion depth refers to the internal overflow pipe.

\subsubsection{Effect on the flow field}

Figures 5-9 demonstrate the dynamic development of the flow field at different immersion depths $(65,75,85,95$ and $105 \mathrm{~mm})$. In terms of the time needed to form a stable flow, the deeper the internal overflow pipe is, the less time needed. It takes $2.1 \mathrm{~s}$ when the immersion depth is $65 \mathrm{~mm}$, but only $1.8 \mathrm{~s}$ when the immersion depth is $105 \mathrm{~mm}$. This indicates that when the depth goes deeper, shorter time is needed for the air to link up between the overflow and the underflow and thus less time to create a steady flow. In terms of the air column shape and stability, when the immersion depth for both the internal and external overflow pipes is equal, the air column is regular, and the internal overflow pipe is fully occupied with air while there is no air in the external pipe. This means the flow is stable at this condition. When 


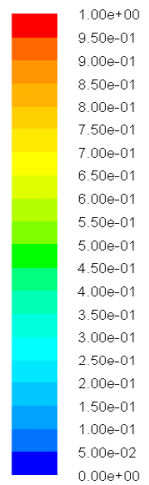

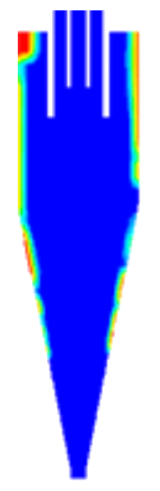

$0.1 \mathrm{~s}$

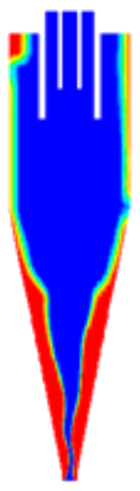

$0.2 \mathrm{~s}$

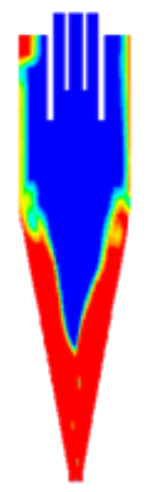

$0.3 \mathrm{~s}$

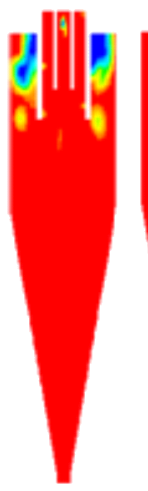

$1.2 \mathrm{~s}$

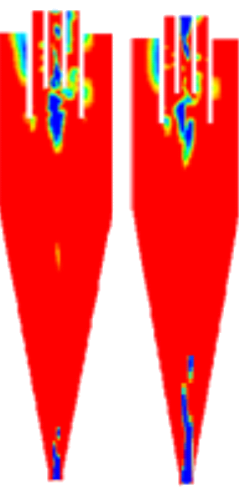

$1.3 \mathrm{~s}$

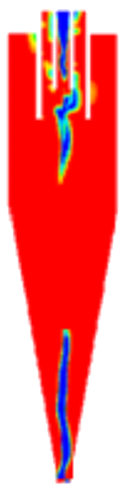

$1.8 \mathrm{~s}$
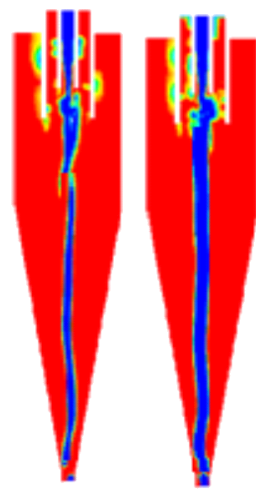

$2.0 \mathrm{~s}$

Fig. 5 The development of flow field in the cyclone with $65 \mathrm{~mm}$ vortex finder length
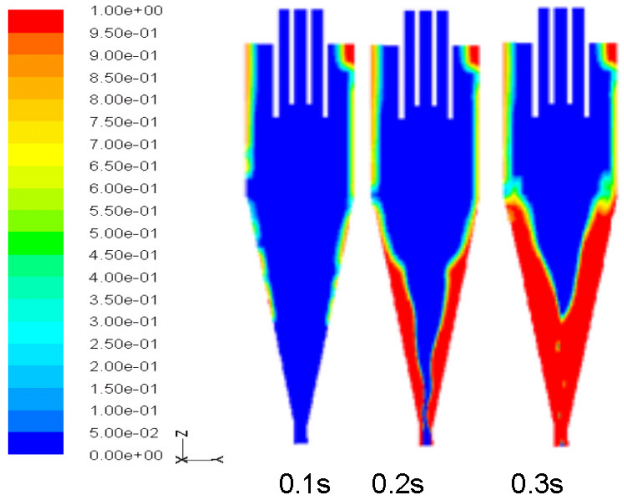
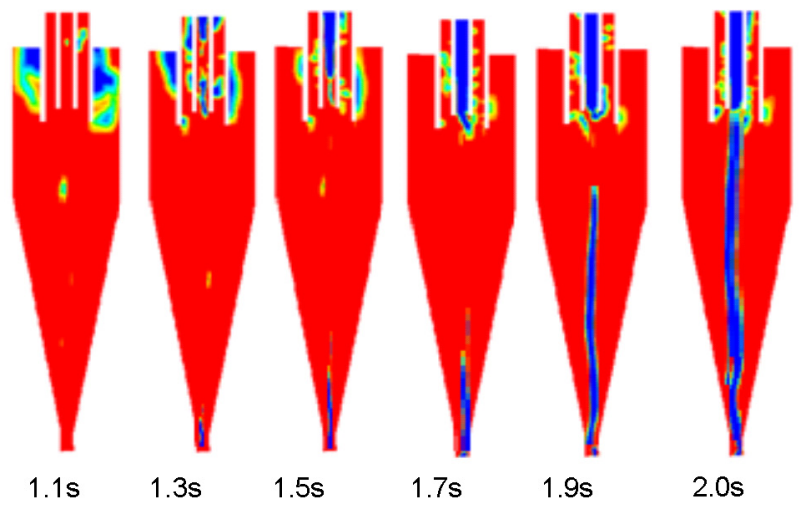

$2.0 \mathrm{~s}$

Fig. 6 The development of flow field in the cyclone with $75 \mathrm{~mm}$ vortex finder length
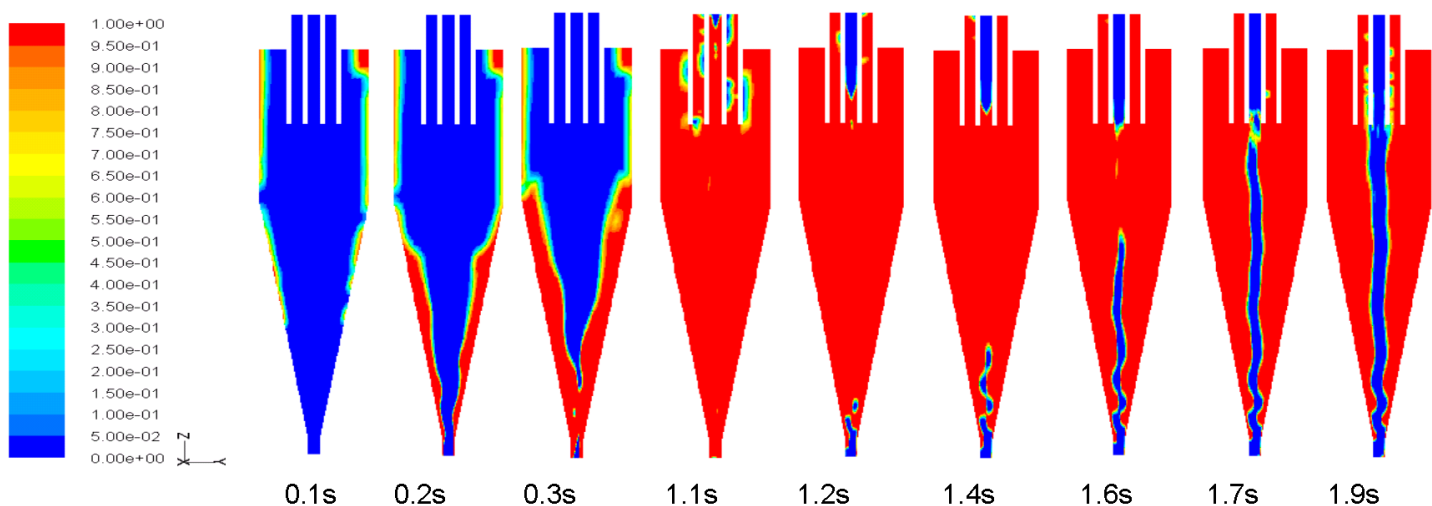

Fig. 7. The development of flow field in the cyclone with $85 \mathrm{~mm}$ vortex finder length

the internal pipe $(65 \mathrm{~mm})$ is shallower than the external pipe $(75 \mathrm{~mm})$, the air column is very irregular as can be seen from Figures 5-6. Especially at the immersion depth, air column is not cylindrical and it exists not only in the internal pipe but also in the external pipe intermittently. This is because when the internal pipe immersion depth is shallower, the fluid moving along the axis has to travel a longer distance vertically and therefore the air appears first in the external overflow pipe and then at the internal pipe. It is also worth mentioning there is a sudden change of the diameter of the air column at the immersion depth. When the internal pipe $(105 \mathrm{~mm})$ is immersed deeper than the external pipe $(95 \mathrm{~mm})$, it can be observed 

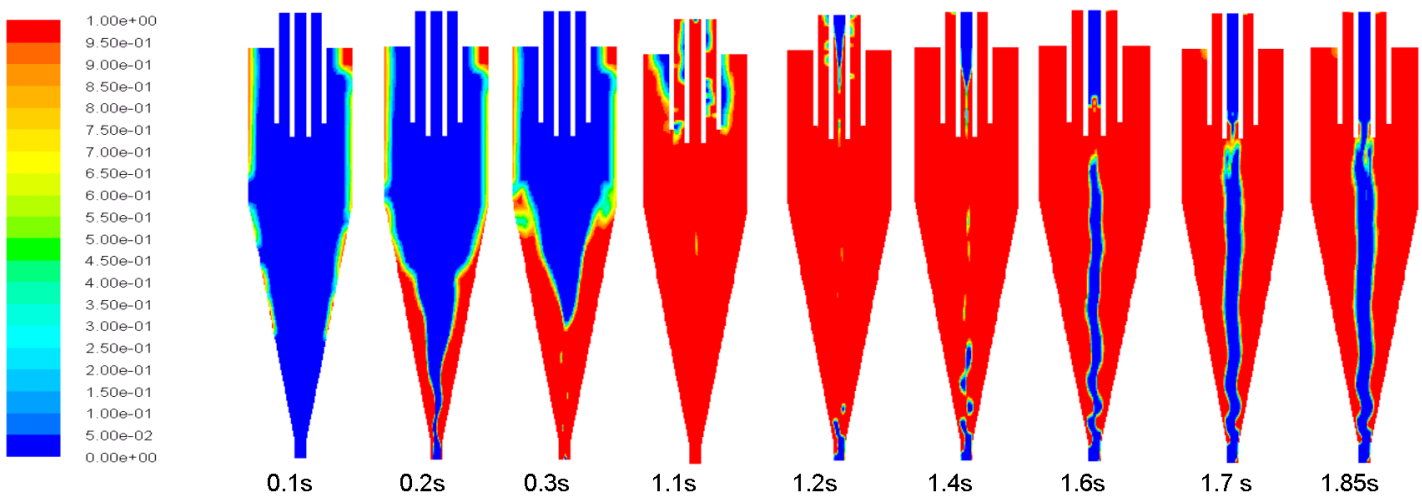

Fig. 8 The development of flow field in the cyclone with $95 \mathrm{~mm}$ vortex finder length
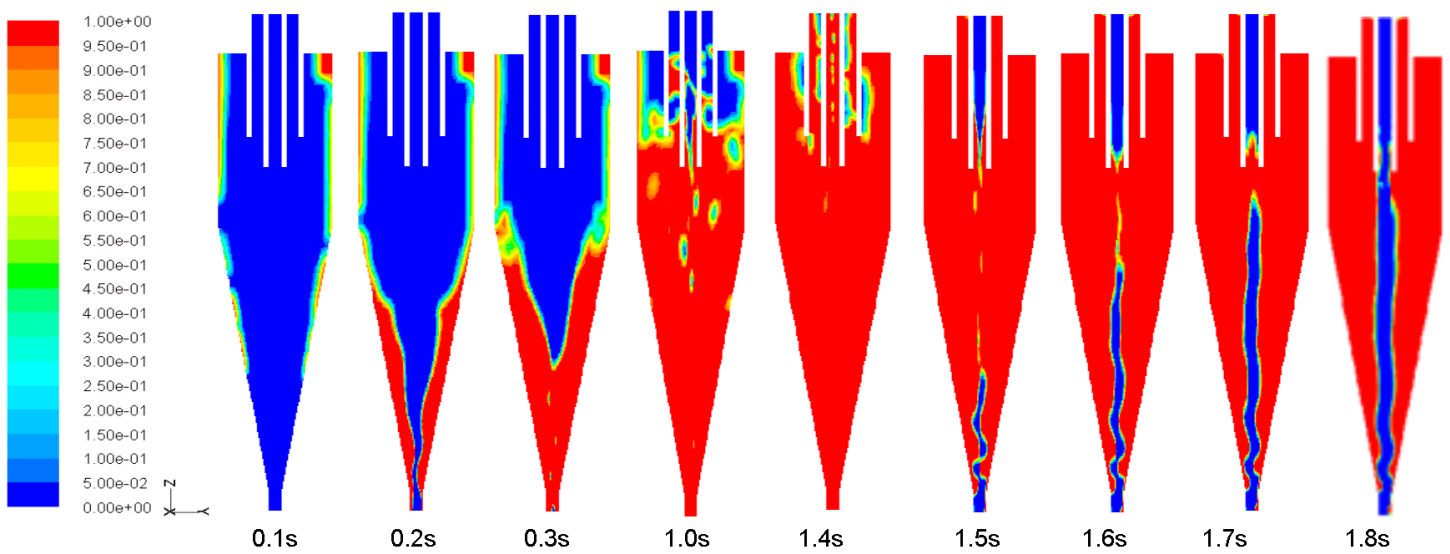

Fig. 9. The development of flow field in the cyclone with $105 \mathrm{~mm}$ vortex finder length

from Figures 8-9 that the internal pipe is filled with air while the external pipe vacant. Again under this condition, there is a sudden change of the diameter of the air column which was very unstable.

On the other hand, the air column diameter is seldom affected by the immersion depth of the internal overflow pipe, which indicates that the energy consumption could not be reduced by changing the immersion depth.

\subsubsection{Effect on the velocity flow field}

Figures 10-12 show field of the tangent, radial and axial velocities for the cyclone separator at the height at $z=100 \mathrm{~mm}$ (cone range) and $z=170 \mathrm{~mm}$ (cylindrical range). It can be seen from Figures 10-11 that both the tangent and radial velocity are not affected by the immersion depth. However, from Figure 12, the immersion depth can affect the axial velocity. In the cone range from the wall to the axis, the axial velocity decreases with an increasing immersion depth. However, the axial velocity right at the axis is just slightly affected by the depth as it is far away from the internal overflow pipe. In the cylindrical range, it is appar- ent that as the depth increases, the axial velocity at the axis decreases.

\subsubsection{Effect on the pressure flow field}

Figure 13 shows the pressure distribution on the sections along the axis at $z=100 \mathrm{~mm}$ and $z=170 \mathrm{~mm}$. It can be found that the static pressure decreased across the separator wall to the axis, and the closer to the axis, the more negative the pressure is. In addition, the static pressure only slightly increases with an increasing depth.

\section{Conclusions}

This paper has analyzed the effects of the immersion depth on the flow properties of the cyclone separator and provided a theoretical discussion for optimizing the structural parameters in the new design of the cyclone separator.

Physical and mathematical model for the cyclone separator with two overflow pipes is built. The analysis of the separator flow field is derived.

The formation and development of the air column is explained. It is determined that when 

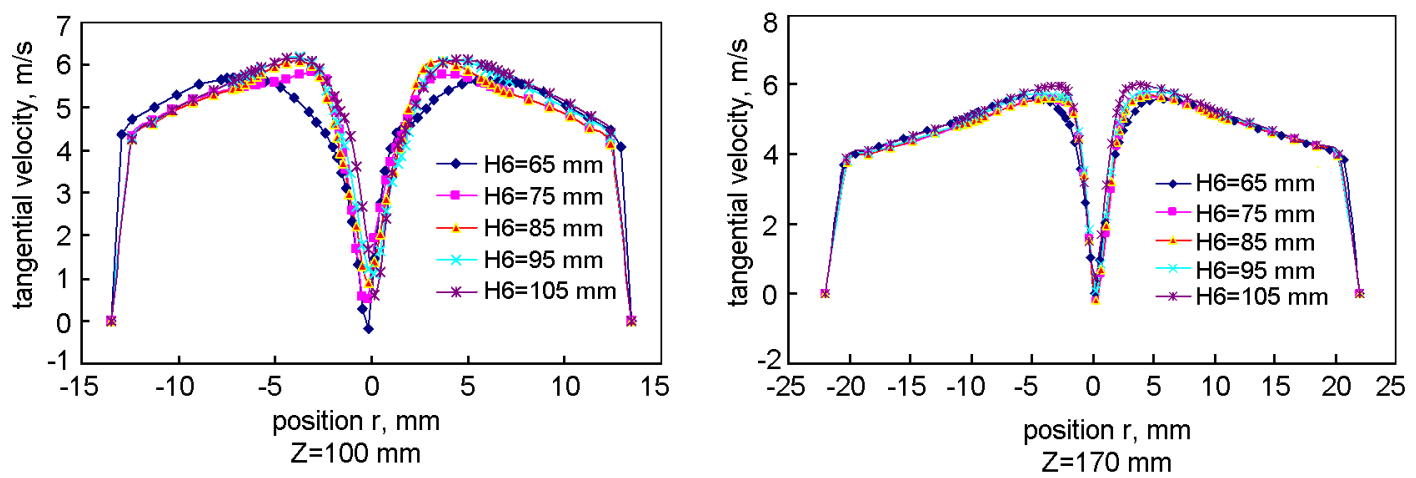

Fig.10 Effect of the vortex finder length on tangential velocity
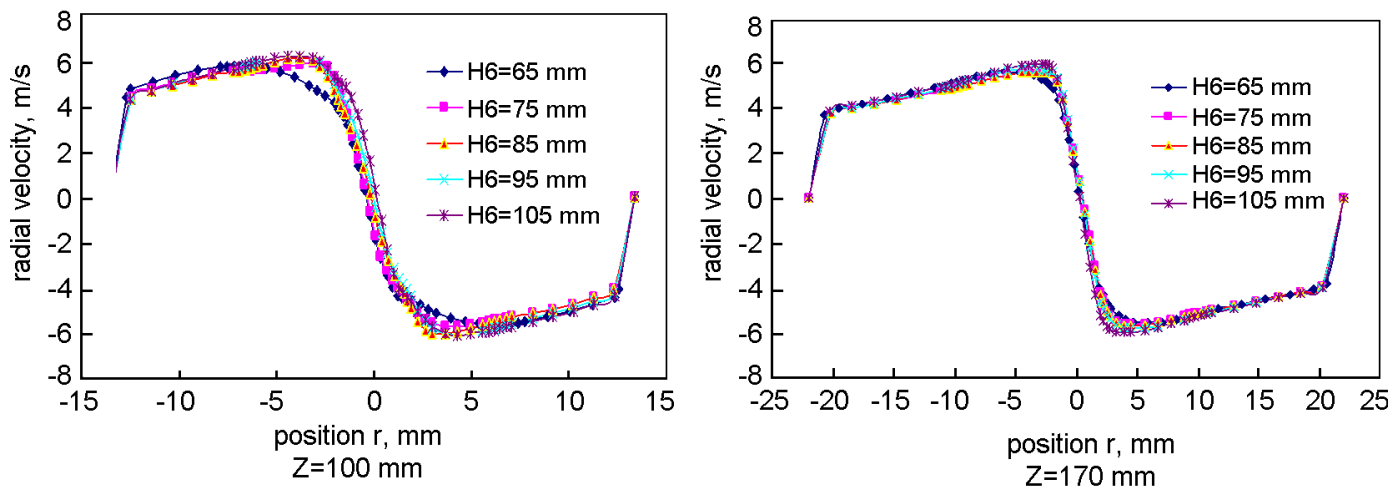

Fig. 11 Effect of the vortex finder length on radial velocity
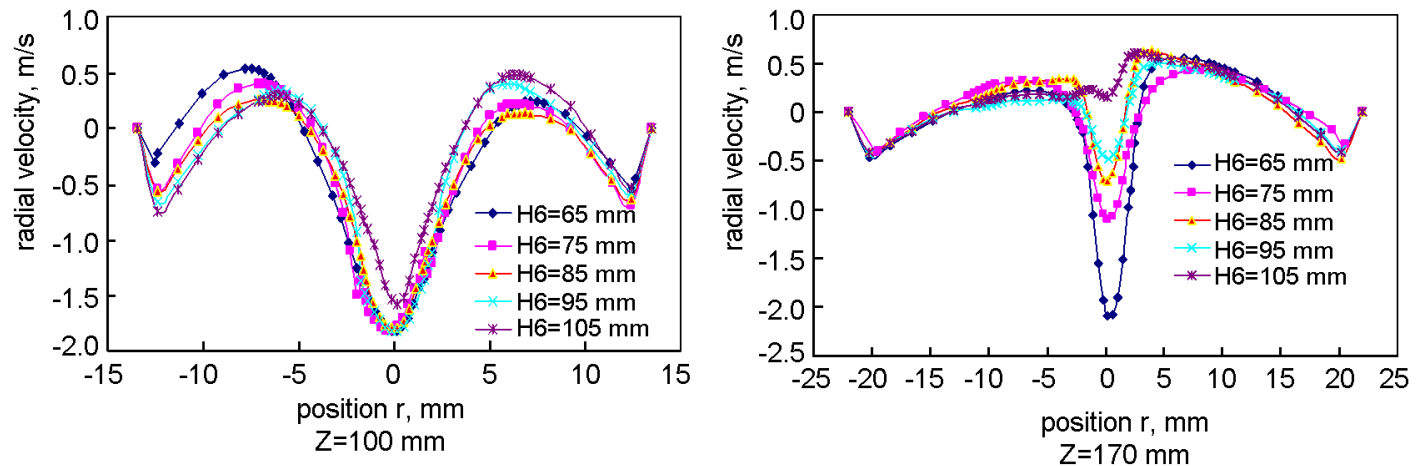

Fig.12. Effect of the vortex finder length on axial velocity
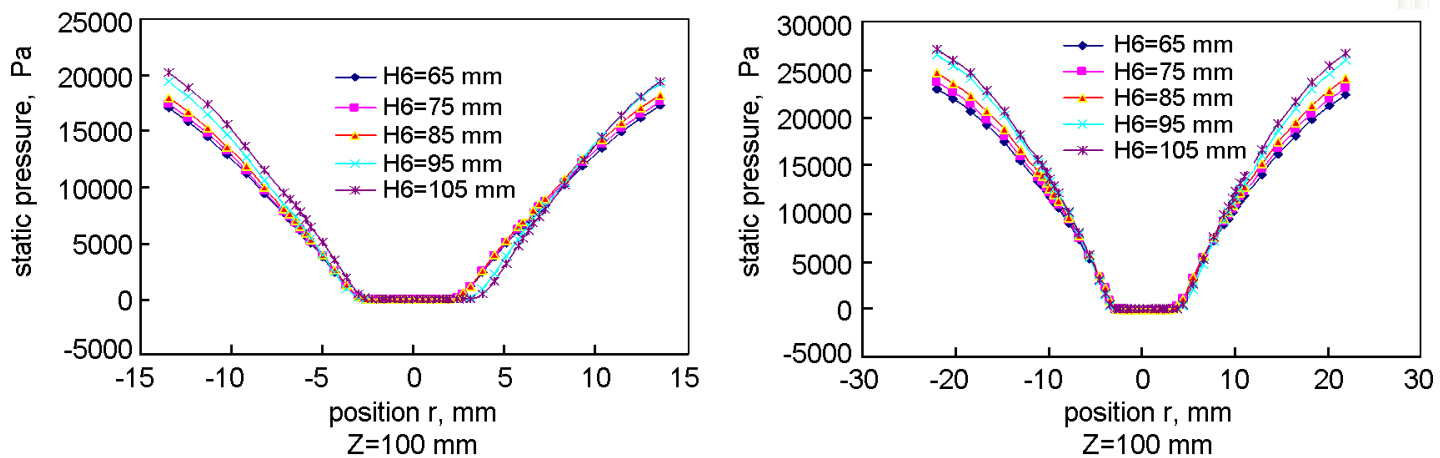

Fig. 13 Effect of the vortex finder length on static pressure 
the immersion depth of the internal overflow pipe is equal to that of the external pipe, the air column is the most regular.

The immersion depth is found not to affect the tangent and radial velocity. However, it has a tremendous effect on the axial velocity especially at the cone range. The axial velocity is observed to decrease with an increasing depth of the internal overflow pipe

\section{Acknowledgements}

This work is supported by the National Natural Science Foundation of China (No.21276145).

\section{References}

1. L.Svarovsky. Hydrocyclones., Holt, Rinchart and Winston, London, 1984.

2. K.T. Hsieh, K.Rajamani, Int. J. Mineral. Process., 22, 223, 1988.

3. Xu jirun, Luo xi. Flow Field Theory of the Hydrocyclone., Beijing, Sciences Press. 1998.

4. M. Ghodrat, S. B. Kuang, A. B. Yu, et al., Ind. Eng. Chem. Res., 52, 16019, 2013.

5. J. A. Delgadillo, G. Rosales-Marin, C. PerezAlonso et al., Chem. Eng., 8, 627, 2013.

6. Sonali Swain, Swati Mohanty, Appl. Math. Modell., 37, 2921, 2013.

7. H. L. Wang, Y. H. Zhang, J. G. Wang, H. L. Liu. Chin. J. Chem. Eng., 20, 212, 2012.

8. G. F. Zhu, J. L. Liow, Y Aneel, Chem. Eng. Res .Des., 90(12), 2135, 2012

9. S. M. Mousavian A. F. Najafi., Arch. Appl. Mech., 79, 395, 2009.

10. Zhang J, You X Y, Niu Z G. Chem. Biochem. Eng., 25, 37, 2011. 